\title{
Drought Resistance of Blue Grama as Affected by Atrazine and $\mathbf{N}$. Fertilizer
}

\author{
D. N. HYDER, W. R. HOUSTON, AND J. B. BURWELL
}

Highlight: Two consecutive summer droughts in north central Colorado caused considerable thinning of blue grama (Bouteloua gracilis) stands, and $N$ fertilizer accentuated the drought effects. However, atrazine, with or without $N$ fertilizer, prevented serious thinning of stands. Consequently, investigations were initiated to test the hypotheses that atrazine created greater resistance to, or tolerance of, drying in crown tissues. Both hypotheses were rejected. It remains to be determined whether the combined effects of weed control, slower transpiration, and changes in root distribution by atrazine treatment may reduce water consumption and, thus, protect blue grama from drought.

This paper validates an unexpected result: namely, atrazine (2-chloro-4-(ethylamino)-6-(isopropylamino)-s-triazine) protected blue grama (Bouteloua gracilis (H.B.K.) Lag. ex Steud.) from drought. As with all unexpected phenomena, this one provokes desire for understanding. How did atrazine protect blue grama from drought?

Atrazine increases the protein concentration of blue grama herbage (Houston and van der Sluijs, 1973) and may cause sufficient change in chemical composition to increase resistance to, or tolerance of, tissue desiccation (Darbyshire, 1974). On the other hand, the effects could be a case of reduction in drought severity. Weed control (Houston and van der Sluijs, 1973; Houston and Hyder, 1976) reduces the intensity of competition and thereby reduces demand for soil water. Furthermore, if atrazine reduces transpiration in blue grama as in other species (Smith and Buchholtz, 1962, 1964; Graham and Buchholtz, 1968; Wills et al., 1963; Coats and Foy, 1974), the delay in soil water depletion could reduce drought severity.

Blue grama, the most important native grass on the central Great Plains, is a warm-season perennial that requires summer precipitation. Fluctuations in stands of blue grama have been known for many years, but its specific dependence on summer precipitation has only recently been quantified (Hyder et al., 1975). Dry summers cause tiller death and thinning of blue grama, whereas wet summers promote thickening of stands. Because $\mathrm{N}$ fertilization accentuates the effects of dry summers (Hyder et al., 1975), future opportunities for increasing forage production by fertilization must be evaluated in terms of ecological risk, as well as of economic gain. Treatments for increasing drought resistance of blue grama could reduce the

Authors are range scientists, Agricultural Research Service, U.S. Department of Agriculture, and student in range science, Colorado State University, Fort Collins.

The report involved cooperative investigations of U.S. Dep. Agr., Agr. Res. Serv., and Colorado State University Experiment Station. Scientific Series Paper No. 2041.

This publication reports research involving pesticides. It does not contain recommendations for their use, nor does it imply that the uses discussed have been registered.

Manuscript received May 2, 1975. ecological risk of natural and induced droughts and provide new management alternatives.

This paper documents the unexpected effect of atrazine in protecting blue grama from drought and explores the possibility that atrazine may increase tissue resistance or tolerance to drying.

\section{Methods}

A study of the effects of atrazine at 0 and $2.2 \mathrm{~kg} / \mathrm{ha}$ was initiated in 1970 at the Central Plains Experimental Range. Each treatment was applied to four 1.4-ha $(3.5$ acre) paddocks. Atrazine and fertilizer were broadcast annually in October 1970-72. The study included four replications of treatments, all on Vona fine sandy loam, a Sandy Plains range site. In each paddock, the stands were sampled annually in June by observing frequency of occurrence of blue grama in 500 placements of a $5-\mathrm{cm}^{2}$ quadrat (Hyder et al., 1965 and 1975). Thus, the effects of each treatment were evaluated by 2,000 quadrat placements, which provide 0.05 confidence limits about mean frequency percentages near $\pm 2 \%$. Frequency percentages by treatments for 1971-73 were adjusted by covariance on those for 1970 . The adjustments were slight, because the stands were very uniform in 1970 .

Precipitation in the summer quarters (June to August) of 1969-1972 amounted to $96,133,50$, and $38 \%$ as much as the 30 -year mean $(14.8 \mathrm{~cm})$. Thus, consecutive dry summers in 1971 and 1972 imposed relatively severe drought.

Plot experiments were initiated in 1973 to study atrazinefertilizer interaction and improvement of deteriorated blue grama. One of those studies, which included atrazine applications of $0,0.6,1.1$, and $2.2 \mathrm{~kg} / \mathrm{ha}$ in four replications, was the source of vegetative material used to study tissue resistance and tolerance to drying.

Perenniality resides in shoot apices, axillary buds, and root primordia of blue grama crowns. Therefore, plants were collected from each plot in 1973 and clipped of herbage and roots to isolate currently active crown tissues, leaving shoot apices enclosed in leaf sheaths (Fig. 1a).

Each sample of crowns was divided into six subsamples. One subsample was oven dried at $110^{\circ} \mathrm{C}$ and ashed at $800^{\circ} \mathrm{C}$ to determine moisture and organic matter percentages. These percentages were presumed applicable to the remaining subsamples, which were subjected to drying at $43^{\circ} \mathrm{C}$ in a partial vacuum (fluctuating from 38 to $50 \mathrm{~cm}$ of mercury) for $0,2,4$, 6 , or 8 hours. It was assumed that the oven temperature by itself was not detrimental, because higher temperatures are common in the field. Resistance to desiccation was determined by the rate of water loss.

After being dried for a specified time, the crowns were pressed into moist soil. The pots were then covered with thin, clear plastic for 1 week of a 2-week growth-performance test in the greenhouse. After 2 weeks, the number of shoots, leafblade length per shoot, proportion of active shoots initiating roots, and root lengths were measured to evaluate tolerance to desiccation (Fig. 1b). 


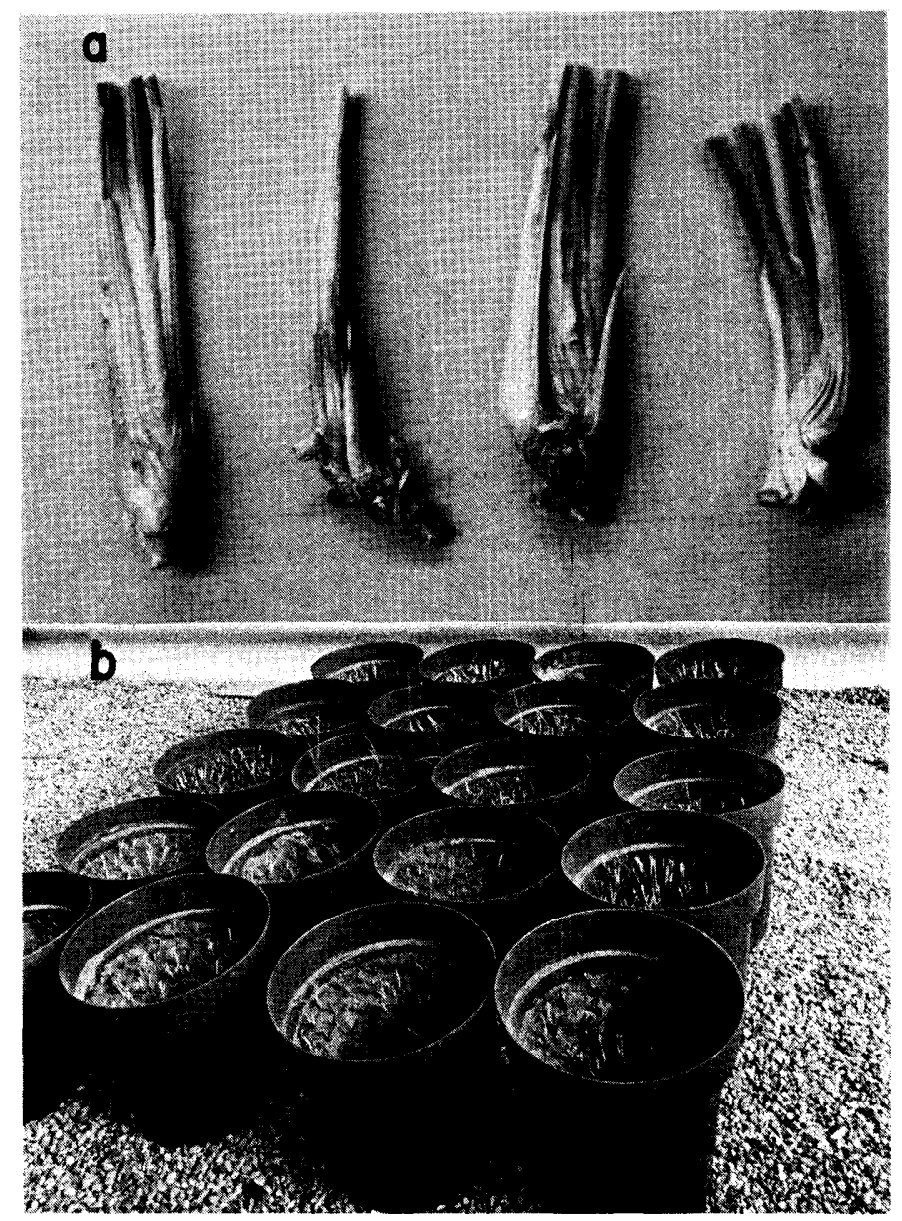

Fig. 1. Growth performance of blue grama crowns: (a) individual crowns prepared for planting and (b) growth of crowns dried in low-temperature vacuum for $8,6,4,2$, and 0 hours (front to rear, respectively).

\section{Results and Discussion}

\section{Effects of Treatments on Blue Grama Stands}

Because blue grama stands were sampled in June, the effects of summer droughts in 1971 and 1972 were detected 1 year later. Untreated blue grama decreased from a frequency of $85 \%$ in 1970 and 1971 to $67 \%$ in 1972 and 56\% in 1973 (Fig. 2, top, solid line). All reductions in stands to less than $60 \%$ frequency were considered serious enough to justify concern and care in management. At confidence limits of $\pm 2 \%$ of mean frequency percentages, atrazine alone significantly reduced the severity of drought effects on blue grama by 1973.

Figure 2 (center) shows changes in blue grama frequency with and without atrazine on paddocks fertilized at $22 \mathrm{~kg}$ $\mathrm{N} / \mathrm{ha}$. With $\mathrm{N}$ alone, blue grama frequency decreased to $58 \%$ in 1972 and $49 \%$ in 1973. Thus, $N$ increased drought severity. At that increased level of drought severity, atrazine protected blue grama at a significant level in 1971, 1972, and 1973.

The most extreme test was provided by paddocks fertilized at $45 \mathrm{~kg} \mathrm{~N} /$ ha (Fig. 2, bottom). With that amount of $\mathrm{N}$ alone, blue grama frequency decreased from $85 \%$ in 1970 to 78,30 , and $27 \%$ in 1971,1972 , and 1973 , respectively. By visual observation, we rated this loss of blue grama as an ecological disaster. Even at this most extreme level of drought severity, atrazine completely protected the blue grama, as shown by a 1973 frequency the same as that on paddocks treated with atrazine alone.
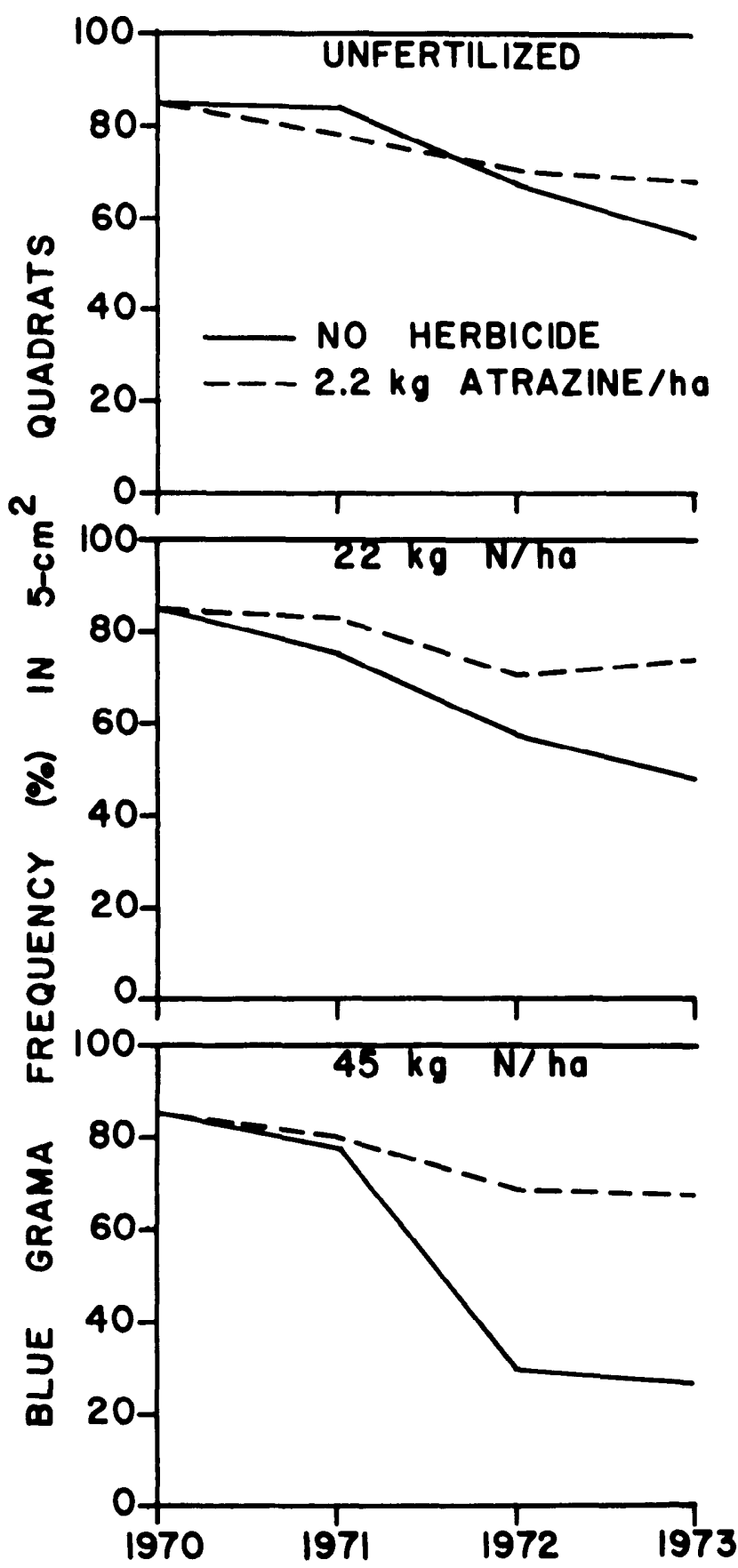

Fig. 2. Frequency of blue grama treated with atrazine and $N$ fertilizer.

\section{Resistance of Crowns to Drying}

Mean moisture percentages for blue grama crowns treated with atrazine were essentially identical among rates of atrazine; however, those treated with atrazine contained significantly less $(P<0.01$ by single degree of freedom analysis) than those from untreated plants (Fig. 3). On the other hand, rates of water loss in partial vacuum were not significantly different in any manner. Water losses were near linear and amounted to about $2.5 \%$ per hour of drying. Consequently, the hypotheses of greater resistance to drying by crowns of plants treated with atrazine is rejected.

\section{Tolerance of Crowns to Drying}

Growth-performance measurements were correlated with percentage of moisture in crowns at time of planting to define 


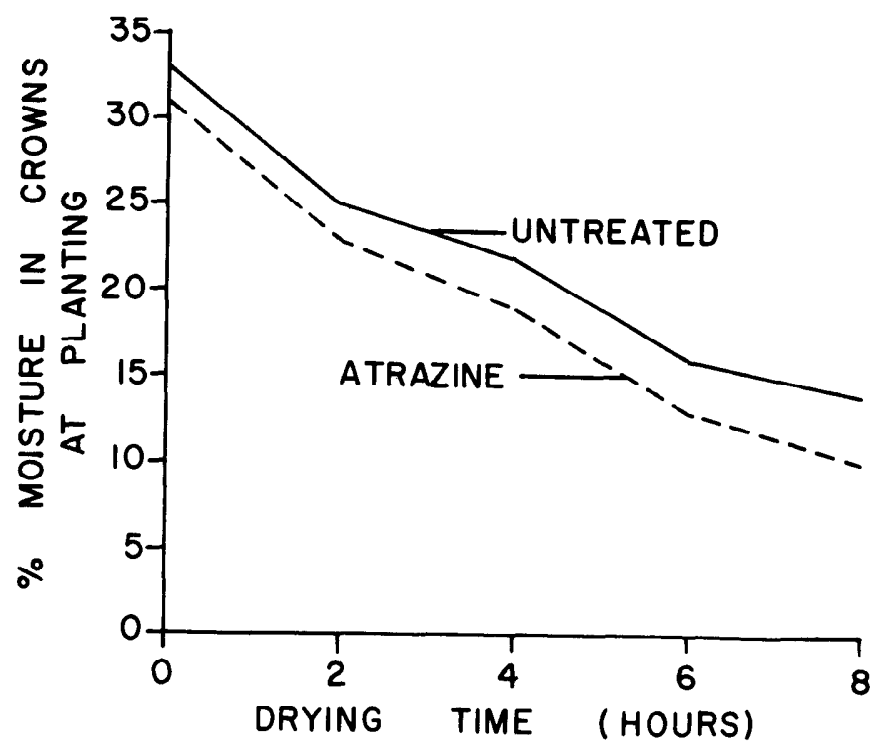

Fig. 3. Moisture content of untreated and treated blue grama crowns dried in vacuum.

tolerance to drying. For the number of shoots initiating leaf growth (called live shoots) per gram of crown organic matter planted, low temperature vacuum drying was detrimental, especially when the moisture content of crowns was reduced below $25 \%$ (Fig. 4). Drying to a moisture content appreciably below $10 \%$ was lethal to all shoot primordia. However, atrazine treatments did not significantly affect the number of live shoots obtained. Consequently, the tolerance to drying shown in Figure 4 represents an average of all treatments. A number of curvilinear functions were evaluated, but all growth evaluations were best defined by regression of growth parameters on the reciprocal of percentage of moisture in crowns at planting.

In all cases, the capacity for root growth was more sensitive and critical than the capacity for shoot growth. Many crowns initiated leaves and failed to initiate roots. Of crowns not dried, only $27 \%$ of live shoots initiated roots in 2 weeks, and vacuum drying quickly reduced the capacity for rooting (Fig. 5).

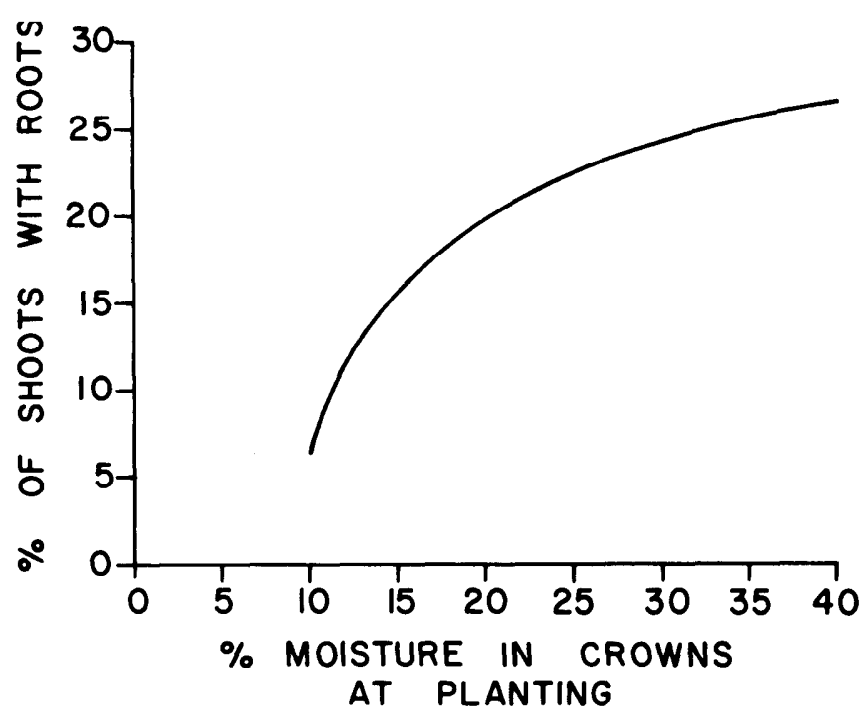

Fig. 4. Number of blue grama live shoots per gram of crown organic matter planted $(\hat{Y})$ as a function of the moisture content of crowns at planting $(X) .\left(\hat{Y}=46.12-459 X^{-1}, r=-0.92, S E E= \pm 4.5\right.$ shoots. $)$

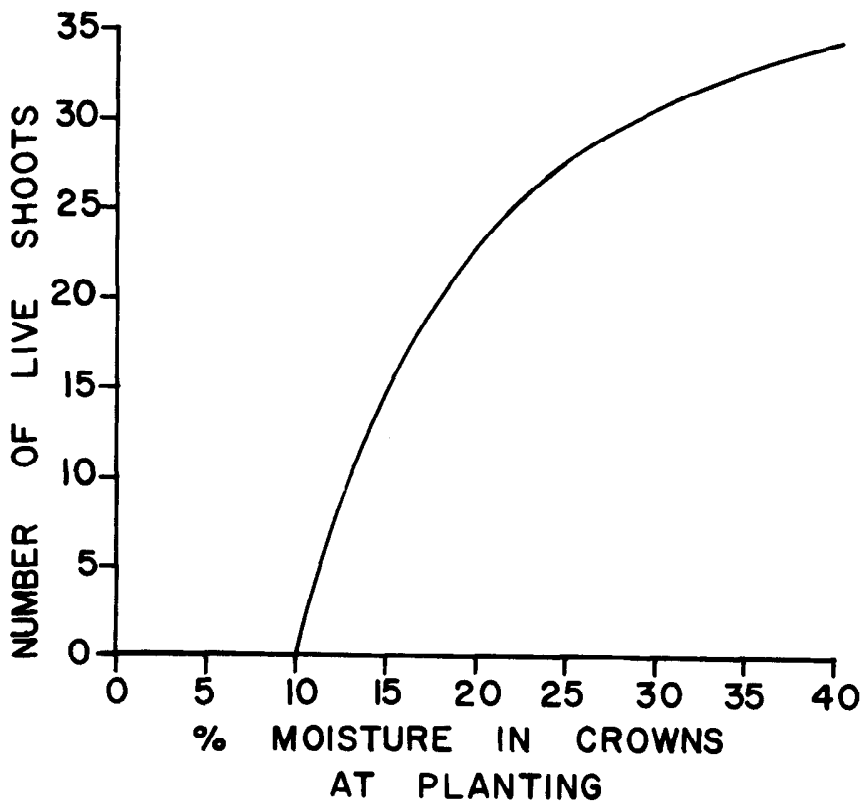

Fig. 5. Percentage of live shoots that initiated roots $(\hat{Y})$, as a function of the moisture content of crowns at planting $(X) . \quad(\hat{Y}=33.6-$ $268 X^{-1}, r=-0.64, S E E= \pm 6 \%$.)

Among the crowns that initiated both shoot and root growth, root lengths were not affected significantly by either atrazine or drying treatments. Mean root length, not counting branches, was $10 \mathrm{~cm}$. The all-or-nothing effects on capacity for roots was very striking. Leaf growth by crowns that failed to initiate roots was very limited, but crowns that initiated both shoots and roots produced very good plants in 2 weeks.

Hypotheses regarding increased resistance or tolerance of blue grama to dehydration of crown tissues by atrazine treatment are both rejected. Consequently, it appears that atrazine must reduce drought severity by the net effects of weed control and/or reduced transpiration, which are the subjects of current investigations.

\section{Literature Cited}

Coats, G. E., and C. L. Foy. 1974. Effects of atrazine-phy tobland oil combinations on ${ }^{14} \mathrm{CO}_{2}$-fixation and transpiration. Weed Sci. $22: 215-220$.

Darbyshire, Ben. 1974. The function of the carbohydrate units of three fungal enzymes in their resistance to dehydration. Plant Physiol. 54:717-721.

Graham, J. C., and K. P. Buchholtz. 1968. Alteration of transpiration and dry matter with atrazine. Weed Sci. 16:389-392.

Houston, W. R., and D. N. Hyder. 1976. Controlling sixweeks fescue on shortgrass range. J. Range Manage. 29:151-153.

Houston, W. R., and D. H. van der Sluijs. 1973. Increasing crude protein content of forage with atrazine on shortgrass range. U.S. Dep. Agr., Agr. Res. Serv., Prod. Res. Rep. No. 153.10 p.

Hyder, D. N., R. E. Bement, E. E. Remmenga, and D. F. Hervey. 1975. Ecological responses of native plants and guidelines for management of shortgrass range. U.S. Dep. Agr. Tech. Bull. 1503.87 p.

Hyder, D. N., R. E. Bement, E. E. Remmenga, and C. Terwilliger, Jr. 1965. Frequency sampling of blue grama range. J. Range Manage. 18:90-93.

Smith, D., and K. P. Buchholtz. 1962. Transpiration rate reduction in plants with atrazine. Science 136:263-264.

Smith, D., and K. P. Buchholtz. 1964. Modification of plant transpiration rate with chemicals. Plant Physiol. 39:572-578.

Van der Sluijs, D. H. 1972. Response of shortgrass range and blue grama (Bouteloua gracilis (H.B.K.) Lag. ex Steud.) plants to $s$-triazine herbicides. $\mathrm{PhD}$ Thesis, Colorado State Univ., $184 \mathrm{p}$.

Wills, G. D., D. E. Davis, and H. H. Funderburk, Jr. 1963. The effect of atrazine on transpiration in corn, cotton, and soybean. Weeds $11: 253-255$. 